\title{
Phosphorus Fractions in Different Soil Orders in India and their Relationship with Soil Properties
}

\author{
Tirunima Patle ${ }^{1}$, V.K. Khaddar ${ }^{1}$, Rishikesh Tiwari $^{2} *$ and Pavan Para $^{3}$ \\ ${ }^{1}$ Department of Soil Science and Agricultural Chemistry, College of Agriculture, ${ }^{3}$ Department \\ of Agronomy, Rajmata Vijayaraje Scindia Krishi Vishwavidyalaya, \\ Gwalior-474003 (M.P.), India \\ ${ }^{2}$ Department of Soil Science \& Agricultural Chemistry, J.N.K.V.V. Jabalpur, \\ Madhya Pradesh, India \\ *Corresponding author
}

\section{Keywords \\ Phosphorus \\ fractions, Vertisol, Inceptisol, Alfisol, Aridisols, $\mathrm{Ca}-\mathrm{P}, \mathrm{Fe}-\mathrm{P}, \mathrm{Al}$ - $\mathrm{P}$, Saloid - $\mathrm{P}$ \\ Article Info \\ Accepted: \\ 15 April 2019 \\ Available Online: \\ 10 May 2019}

\section{A B S T R A C T}

In present study, phosphorus fractions in representative agricultural soils belonging to four soil orders Vertisols, Inceptisols, Alfisols and Aridisols. The experiment was conducted at the carry out the investigation a laboratory in the lab of Japanese International Cooperation Agency (JICA), College of Agriculture, Indore. Result revealed that the highest soil pH analysed in Vertisols with the range 7.9 followed by Aridisols range 7.8, Alfisols range 6.6, and low $\mathrm{pH}$ found in Inceptisols, which 6.4 soil orders, respectively. The EC was existed as normal in all the orders $<1 \mathrm{dS} \mathrm{m}-1$ at $25^{\circ} \mathrm{C}$ high range Alfisols. The organic carbon content was recorded in different soil orders ranged from 4.6, 1.2, 0.76 to $0.43 \mathrm{~g}$ $\mathrm{kg}^{-1}$. The clay ranged from $56,24.3,16.97,7.8$, percentage. The available $\mathrm{N}$ content in soils varied from $334,280,358$ to $180 \mathrm{~kg} \mathrm{ha}^{-1}$ in different soil orders was significant positively correlated. The available phosphorus content in four soils orders varied from $16.9,27.45,14.9$ to $6.25 \mathrm{~kg} \mathrm{ha}^{-1}$. The available $\mathrm{K}$ ranged from $425,224.4,546$ to $697.2 \mathrm{~kg}$ $\mathrm{ha}^{-1}$. The available N, P and K were low to medium in different soil orders. Vertisols and Inceptisols. The correlation studies of different fractions of phosphorus under different rates of phosphorus application showed positive correlation with $\mathrm{Ca}-\mathrm{P}$ in Vertisols and Aridisols, while Fe-P, Al - P Showed highly significant correlation with Inceptisols and Alfisols, this can be infused that the applied phosphorus fixed as $\mathrm{Ca}-\mathrm{P}$ in Vertisols while in the case of Alfisols and Inceptisols, the applied phosphorus is fixed as Al-P and Fe-P and Saloid - $\mathrm{P}$ did not show much response to different fraction of phosphorus except in Vertisols.

\section{Introduction}

Phosphorus in soil present in organic and inorganic forms. Only 10 to 30 per cent of the freshly applied phosphate is utilized by crop plants and rest goes into the formation of different $\mathrm{P}$ compounds of varying solubility which later serve as potential source of $P$ for plants (Kanwar, 1976). Phosphorus (P) is essential element for plant growth as well as 
an important component in the developmental processes of agricultural crops (Withers et al., 2008). Approximately two-thirds of inorganic $\mathrm{P}$ and one third of organic $\mathrm{P}$ are not available in soil, especially in soils of variable charges. The rate of $\mathrm{P}$ use during crop growth is very low. Phosphates fixed by $\mathrm{Fe}, \mathrm{Al}$, and $\mathrm{Ca}$ in soils is a major cause of low phyto availability (McBeath et al., 2005), because at least 70 to $90 \%$ of $\mathrm{P}$ that enters the soil is fixed, making it difficult for plants to absorb and use (Lei et al., 2004).

The $\mathrm{P}$ is a critical element in agricultural ecosystem given its complex transformation in soil thus making its availability to plant difficult especially in tropics. Its deficiency is one of the major nutritional constraints to crop production in Indian vertisols (Bansal and Sekhon, 1994). Muralidharudu et al., (2011) reported only 8 and $11 \%$ districts as high $\mathrm{P}$ in India and Madhya Pradesh, respectively. Soil phosphorus exists in inorganic $\mathrm{P}$ and organic $\mathrm{P}$ forms.

These $\mathrm{P}$ forms differ in their behavior and fate in soils (Turner et al., 2007). The organic P can be released through mineralization processes mediated by soil organisms and plant roots in association with phosphates secretion. These processes are highly influenced by soil moisture, temperature, surface physical chemical properties, and soil $\mathrm{pH}$ and Eh. Organic P transformation has a great influence on the overall bioavailability of $\mathrm{P}$ in soil (Turner et al., 2007).

\section{Materials and Methods}

\section{Description of study area and sites}

The experiment was conducted at the carry out the investigation a laboratory during year 2016 in the lab of Japanese International Cooperation Agency (JICA), College of Agriculture, Indore. A composite sample of four different soils which belong to different soil orders are randomly collected from four different cities (Nasik,- Banglore, - Indore, Gwalior). All the possible technical precautions as prescribed for standard soil sampling have been followed. Samples were, air - dried in the shade and grounded by wooden roller, thereafter sieved through 2 $\mathrm{mm}$ mesh and stored in polyethylene bags. The soil samples thus obtained were subjected to various chemical analyses to assess the single value of chemical properties of soil. The soil of the experimental site is (1). Soil of Nasik - Inceptisols. (2). Soil of Bengaluru Alfisols, (3). Black soil of Indore - Vertisols, (4). Alluvial soil of Gwalior - Aridisols. The experiment was laid out in permanent plot with: 7 treatments comprised of different dosages of P:(1) Control P No phosphorus, (2). - $40 \mathrm{~kg} \mathrm{P},(3)$. $-80 \mathrm{~kg} \mathrm{P}$, (4).- $120 \mathrm{~kg}$ $\mathrm{P},(5)$. - $160 \mathrm{~kg} \mathrm{P,} \mathrm{(6).} \mathrm{-} 200 \mathrm{~kg} \mathrm{P,} \mathrm{(7).} \mathrm{-.} 400$ $\mathrm{kg} \quad \mathrm{P}$, Statistical design: completely randomized design, with three replications for each treatment was selected for the study.

\section{Physico-chemical properties of soils}

The soil $\mathrm{pH}$ was measured in a soil: water ratio of 1: 2.5 using the $\mathrm{pH}$ meter and supernatant of same was used for electrical conductivity determination with the help of conductivity-meter (Jackson, 1973). Organic carbon in soil was determined using method as described by Walkley and Black (1934). Available nitrogen by alkaline - $\mathrm{KMnO}_{4}$ method (Subbiah and Asija, 1956). Available phosphorus in soil was determined by $0.5 \mathrm{M}$ $\mathrm{NaHCO}_{3}(\mathrm{pH}$ 8.5) extraction method ( Olsen et al., 1954 ) for Inceptisol and Vertisol and Bray - Kurtz no 1 method (Bray and Kurtz, 1945) for Alfisol, followed by colour development by ascorbic acid method Available potassium $(\mathrm{K})$ was extracted by $1 \mathrm{~N}$ neutral $\mathrm{NH}_{4} \mathrm{OAc}$ and determined by flame photometer (Jackson, 1973). The sand, silt and clay contents (\%) were determined by hydrometer method (Piper, 1950). 
Determinations of phosphorus fractions soil order

The different $\mathrm{P}$ fractions by adopting by Chnag and Jhakson (1957) are used to determine fractions of $\mathrm{P}$ as Saloid - P, Al- P, $\mathrm{Fe}-\mathrm{P}, \mathrm{Ca}$ - P. Simple correlation coefficient analyses between soil properties and fractions of $\mathrm{P}$ were computed by standard statistical methods. The soil extractant for various fractions in sequence were as follow, Saloid $\mathrm{P}$ extracted by $1 \mathrm{~N} \mathrm{NH}_{4} \mathrm{CI}, \mathrm{Al}$ - P extracted by $0.5 \mathrm{~N} \mathrm{NH}_{4} \mathrm{~F}$ buffered at $\mathrm{pH}$ 8.2, Fe - $\mathrm{P}$ extracted by $0.1 \mathrm{M} \mathrm{NaOH}, \mathrm{P}$ extracted by 0.5 $\mathrm{N} \mathrm{H}_{2} \mathrm{SO}_{4}$.

\section{Flow chart of phosphorus fractions}

$1 \mathrm{~g}$ of soil samples taken in a $50 \mathrm{ml}$ centrifuge tube

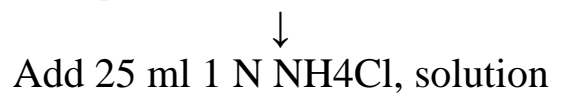

Shake it for $1 / 2$ hour and centrifuge it for $5 \mathrm{~min}$

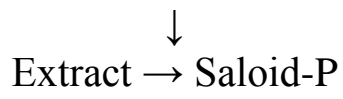

$\downarrow$

$25 \mathrm{ml}$ of $0.5 \mathrm{~N} \mathrm{NH} 4 \mathrm{~F}$ was added in the same tube after filtering

Shake it for $1 / 2$ hour and centrifuge it for $5 \mathrm{~min}$

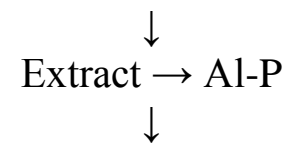

The residue of tube is washed by adding $25 \mathrm{ml}$ of $\mathrm{NaCl}$

$25 \mathrm{ml}$ of $0.1 \mathrm{M} \mathrm{NaOH}$, was added in the same tube after filtering

Shake it for 17 hours and then centrifuging of $5 \mathrm{~min}$

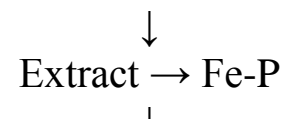

The residue of tube is washed by adding $25 \mathrm{ml}$ of $\mathrm{NaCl}$

$25 \mathrm{ml}$ of $0.1 \mathrm{M} \mathrm{NaOH}$, was added in the same tube after filtering

Shake it for 1hoursand than centrifuging of 5 min

The residue of tube is washed by adding $25 \mathrm{ml}$ of $\mathrm{NaCl}$

$25 \mathrm{ml}$ of $0.5 \mathrm{~N} \mathrm{H} 2 \mathrm{SO} 4$ was added in the same tube after filtering

Shake it for 1 hours and then centrifuging of $5 \mathrm{~min}$

$$
\stackrel{\downarrow}{\text { Extract }} \rightarrow \text { Ca-P }
$$




\section{Results and Discussion}

\section{Status of physico - chemical properties of soil}

The soil $\mathrm{pH}$ of different soil order of different place, (Table 1) found to be, Vertisols - 7.9, Aridisols - 7.8, Alfisols - 6.6, Inceptisols 6.4 , soil orders, respectively. The EC ranged from $0.14,0.45$ and $1.95,0.2 \mathrm{dS} \mathrm{m}^{-1}$. It was no safe in limit the Alfisols four soil order $<1$ $\mathrm{dSm}^{-1}$ at $25^{\circ} \mathrm{C}$.

The organic carbon content in soil ranged from vertisols - 4.60, aridsols - 1.2, Alfisols 0.76 , Inceptisols - $0.43 \mathrm{~g} \mathrm{~kg}^{-1}$ in different orders of soil, respectively. However, organic carbon content in Inceptisols was observed to be low which is having value of $0.2 \mathrm{~g} \mathrm{~kg}^{-1}$ respectively. The Clay content was found to be, Vertisols 56, Aridisols 24.3, Alfisols 16.97, Inceptisols 7.8, percentage soil orders, respectively. Clay content was found to be low in Inceptisols and the high in Vertisols Similar results were also reported by Matike et al., (2011) and Singh (2014).

\section{Available major nutrients status in soils}

In Vertisols $334 \mathrm{~kg} \mathrm{ha-}{ }^{1}$, Aridisols $280 \mathrm{~kg}$ $\mathrm{ha}^{-1}$, Alfisols $358 \mathrm{~kg} \mathrm{ha}^{-1}$, Inceptisols $180 \mathrm{~kg}$ $\mathrm{ha}^{-1}$, soil orders, respectively. In Inceptisols low value in Alfisols, it was recorded to be $358 \mathrm{~kg} \mathrm{ha}^{-1}$, respectively higher value.

The low to medium nitrogen content in the soils is attributed due to high temperature, removal of organic matter leading to nitrogen deficiency.

The medium nitrogen status may be due to application of $\mathrm{N}$ fertilizer recommended for the crops. Soils with higher levels might be the contribution from the legumes crops and very little tillage. Similar results were reported by Dubliya (2011) and Singh et al., (2014); Ravikumar and Somashekar (2014).

\section{Available P}

The available $\mathrm{P}$ content in In Vertisols 16.9 $\mathrm{kg} \mathrm{ha}^{-1}$, Aridisols $27.45 \mathrm{~kg} \mathrm{ha}^{-1}$, Alfisols 14.9 $\mathrm{kg} \mathrm{ha}^{-1}$, Inceptisols $6.25 \mathrm{~kg} \mathrm{ha}^{-1}$, soil orders, respectively. In Inceptisols low value, In Aridisols, it was recorded to be respectively higher value. The high accumulation of $\mathrm{P}$ in soils is attributed to the regular application of phosphatic fertilizers and the immobile nature of phosphate ions in soils. Results were supported by Ravikumar and Somashekar (2014) similar results were reported by Dubliya, 2011 and Singh et al., (2014).

\section{Available K}

The available K content in In Vertisols $425 \mathrm{~kg}$ ha- $^{1}$, Aridisols $224.4 \mathrm{~kg} \mathrm{ha}^{-1}$, Alfisols $546 \mathrm{~kg}$ $\mathrm{ha}^{-1}$, Inceptisols $180 \mathrm{~kg} \mathrm{ha}^{-1}$, soil orders, respectively. In Inceptisols low value, In Alfisols, it was recorded to be $546 \mathrm{~kg} \mathrm{ha}^{-1}$, respectively higher value. The high status of $\mathrm{K}$ in these soils may be due to predominance of $\mathrm{K}$ rich minerals in parent material. Similar results reported by Ravikumar and Somashekar (2014).

\section{Distribution of the different forms of $P$ (saloid-P, Al-P, Fe-P, Ca-P) in the studied soils}

The data pertaining to distribution of different forms of phosphorus and their percentage contribution to the total phosphorus in the different soils order are given in Table 1 and Figure 1, 2, 3, 4 Among the various forms $\mathrm{Ca}$ - $\mathrm{P}$ was present in a high quantity $\left(142 \mathrm{kgha}^{-1}\right)$ followed by $\mathrm{Fe}-\mathrm{P}\left(29 \mathrm{Kgha}^{-1}\right), \mathrm{Al}-\mathrm{P}$ $\left(12 \mathrm{Kgha}^{-1}\right)$ Saloid - P (9.0Kgha) in soil order Vertisols, sequentially in Inceptisols $\mathrm{Fe}-\mathrm{P}$ was dominant $\mathrm{P}$ fraction $\left(51.1 \mathrm{kgha}^{-1}\right)$ followed by $\mathrm{Ca}$ - P (36.4kgha $\left.{ }^{-1}\right)$, Saloid - P (24.02 $\mathrm{kgha}^{-1)}$, Al - P (4.0 kgha $\left.{ }^{-1}\right)$, Alfisols has $\mathrm{Fe}$ - P (57.0kgha $\left.{ }^{-1}\right)$ followed by $\mathrm{Ca}$ $\mathrm{P}\left(31.9 \mathrm{kgha}^{-1}\right), \mathrm{Al}-\mathrm{P}\left(29.0 \mathrm{Kgha}^{-1}\right)$, at last Saloid - P(5.0 kgha $\left.{ }^{-1}\right)$ and in order Aridisols 
contains $\mathrm{Ca}-\mathrm{P}\left(112.0 \mathrm{kgha}^{-1}\right), \mathrm{Fe}-\mathrm{P}(50.2$ $\left.\mathrm{kgha}^{-1}\right)$, Saloid-P(28.5 $\left.\mathrm{Kgha}^{-1}\right), \mathrm{Al}-\mathrm{P}(2.4$ Kgha $^{-1}$ ) (Table 2).

\section{Phosphorus fractions in different soil} orders

\section{Vertisols}

In vertisols the $\mathrm{P}$ fractions were analysed in soil. The data pertaining to distribution of different forms of phosphorus and their percentage contribution to the total phosphorus are given in Table 3. Among the various forms, $\mathrm{Ca}-\mathrm{P}$ fraction was dominant fraction in this soil which ranged from 142 to $432 \mathrm{kgha}^{-1}$, Compared to other $\mathrm{P}$ fractions Saliod - P was present in a small quantity which ranged from 9 to $20 \mathrm{kgha}^{-1}$, the contribution of $\mathrm{Fe}-\mathrm{P}$ in phosphorus fractions is about 29 to $112 \mathrm{kgha}^{-1}$ followed by $\mathrm{Al}-\mathrm{P}$ which ranged from 12 to $38 \mathrm{kgha}^{-1}$. The dominance of different inorganic $\mathrm{P}$ fractions in these soils followed the order: $\mathrm{Ca}-\mathrm{P}>\mathrm{Fe}-\mathrm{P}$ $>$ A 1 -P>Saloid - Ojo et al., (2015) stated that changes in the values of the $\mathrm{P}$ fractions in soils are significantly affected by soil type. Soil orders differ in their total $\mathrm{P}$ content because of interactions among soil parent material, weathering, and other pedogenic processes. In general, total $\mathrm{P}$ content is low in strongly weathered soil soils orders and high in young soil orders (Yang and Post, 2011). The content of the Ca-P ranks highest which was an indication of the fact that Ca-P form contributed to the major source of $\mathrm{P}$ in black soil as reported by Kaushal (1995), Subehia et al., (2005), Samadi (2006) and Garg and Milkha (2010).

\section{Inceptisols}

The result after analysis the $\mathrm{P}$ fractions were in soil. The data pertaining to distribution of different forms of phosphorus and their percentage contribution to the total phosphorus are given in Table 4. Among the various forms, $\mathrm{Fe}-\mathrm{P}$ fraction was dominant fraction in this soil which ranged from 69.1 to $338.0 \mathrm{kgha}^{-1}$, Compared to other $\mathrm{P}$ fractions $\mathrm{Al}$ - $\mathrm{P}$ was present in a small quantity which ranged from 4.0 to $17.8 \mathrm{kgha}^{-1}$, the contribution of $\mathrm{Ca}-\mathrm{P}$ in phosphorus fractions is about 51.5 to $119.0 \mathrm{kgha}^{-1}$ followed by Saloid-P which ranged from 24.0 to 74.0 $\mathrm{kgha}^{-1}$. The dominance of different inorganic $\mathrm{P}$ fractions in these soils followed the order: $\mathrm{Fe}-\mathrm{P}>\mathrm{Ca}-\mathrm{P}>$ Saloid - P > Al - P. Among the different $\mathrm{P}$ fractions, $\mathrm{Ca}$-bound $\mathrm{P}$ was the dominant fraction in the Vertisols and Alfisols. The next-dominant fraction was non occluded $\mathrm{Al}$ and Fe-bound $\mathrm{P}$, which was highest in the Alfisols and Vertisols. $P$ occluded with in Fe-oxides and hydrous oxides fractions was highest in the Vertisol. In Alfisols the amount and type of clay mineral especially $1: 1$ type clay minerals may contribute to more $\mathrm{P}$ sorption especially in tropical soil, particularly with low $\mathrm{pH}$ and high activity of $\mathrm{Al}$ and $\mathrm{Fe}$ (Dolui and Dasgupta, 1998).

\section{Alfisols}

The data on pertaining to distribution of different forms of phosphorus and their percentage contribution to the total phosphorus are given in Table 5.Among the various forms, $\mathrm{Fe}-\mathrm{P}$ fraction was dominant fraction in this soil which ranged from 57.0 to $273.8 \mathrm{kgha}^{-1}$, Compared to other P fractions Saloid - P was present in a small quantity which ranged from 5.0 to $27.0 \mathrm{kgha}^{-1}$, the contribution of $\mathrm{Al}-\mathrm{P}$ in phosphorus fractions is about 29.0 to $132.0 \mathrm{kgha}^{-1}$ followed by $\mathrm{Ca}$ $\mathrm{P}$ which ranged from 31.9 to $89.0 \mathrm{kgha}^{-1}$. The dominance of different inorganic $\mathrm{P}$ fractions in these soils followed the order: $\mathrm{Fe}-\mathrm{P}>\mathrm{A}$ l$\mathrm{P}>\mathrm{Ca}-\mathrm{P}>$ Saloid - $\mathrm{P}$. The results are in agreement with the findings of Patgundi et al., (1996). High P was reported in inceptisols which had little or no weathering or with very 
low decomposition (Yang and Post, 2011). Organic amendments are known to increase $\mathrm{P}$ availability in $\mathrm{P}$ fixing soils by governing the P fractions in soils (Reddy et al., 1999).

\section{Aridisols}

The data pertaining to distribution of different forms of phosphorus and their percentage contribution to the total phosphorus are given in Table 6. Among the various forms, $\mathrm{Ca}-\mathrm{P}$ fraction was dominant fraction in this soil which ranged from 112.0 to $365.0 \mathrm{kgha}^{-1}$, compared to other $\mathrm{P}$ fractions $\mathrm{Al}-\mathrm{P}$ was present in a small quantity which ranged from 2.4 to $26.0 \mathrm{~kg} \mathrm{ha}^{-1}$, the contribution of $\mathrm{Fe}-\mathrm{P}$ in phosphorus fractions is about 50.2to 134.0 $\mathrm{kgha}^{-1}$ followed by Saloid - P which ranged from 25.8 to $65.0 \mathrm{kgha}^{-1}$. The dominance of different inorganic $\mathrm{P}$ fractions in these soils followed the order: $\mathrm{Ca}-\mathrm{P}>\mathrm{Fe}-\mathrm{P}>$ Saloid $\mathrm{P}>\mathrm{Al}-\mathrm{P}$. To show the difference in the magnitude of fixation of Phosphorus in different soil order the graph has been plotted between average value of \% fixation and fractions of $\mathrm{P}$ in different soil order.

The fixation capacity of Aridisols increased significantly up to $93.7 \%$. Gupta (1965) in a study found that applied Soluble-P was fixed in $24 \mathrm{hr}$ but gradually increased upto $30-45$ days depending upon the type of soil and thereafter it remain constant.

Table.1 Chemical property of soils

\begin{tabular}{|c|c|c|c|c|c|c|}
\hline S.No. & Properties & Vertisols & Aridisols & Alfisols & Inceptisols & Reference \\
\hline 1 & \multicolumn{6}{|c|}{ Mechanical composition } \\
\hline & Sand \% & 13.15 & 57.9 & 59.86 & 40.6 & \multirow{3}{*}{$\begin{array}{l}\text { Hydrometrice } \\
\text { method (Piper, } \\
\text { 1950) }\end{array}$} \\
\hline & Silt $\%$ & 30.85 & 17.8 & 23.17 & 51.9 & \\
\hline & Clay $\%$ & 56 & 24.3 & 16.97 & 7.8 & \\
\hline 2 & Soil pH & 7.9 & 7.8 & 6.6 & 6.4 & Piper (1950) \\
\hline 3 & $\mathrm{EC}\left(\mathrm{dSm}^{-1}\right)$ & 0.14 & 0.45 & 1.95 & 0.2 & Piper (1950) \\
\hline 4 & Organic carbon $(\%)$ & 4.6 & 1.2 & 0.76 & 0.43 & $\begin{array}{l}\text { Walkley - Black } \\
\text { method (1934) }\end{array}$ \\
\hline 5 & $\begin{array}{c}\text { Available N } \\
\left(\mathrm{Kg} \mathrm{ha}^{-1}\right)\end{array}$ & 334 & 280 & 358 & 180 & $\begin{array}{l}\text { Kjeldahl method } \\
\text { (Black (1965) }\end{array}$ \\
\hline 6 & $\begin{array}{c}\text { Available K } \\
\left(\mathrm{Kg} \mathrm{ha}^{-1}\right)\end{array}$ & 425 & 224.4 & 546 & 697.2 & $\begin{array}{l}\text { Flame Photometer } \\
\text { Method by } \\
\text { Jackson (1973) }\end{array}$ \\
\hline 7 & $\begin{array}{l}\text { Available P } \\
\left(\mathrm{Kg} \mathrm{ha}^{-1}\right)\end{array}$ & 16.9 & 27.45 & 14.9 & 6.25 & Olsen (1954), \\
\hline
\end{tabular}

Table.2 Distribution of different forms of phosphorus

\begin{tabular}{|c|c|c|c|c|c|c|}
\hline ORDER & SOILS & SALOID-P & Al-P & Fe-P & Ca-P & AVAILABLE P \\
\hline Vertisols & Indore & 9.0 & 12 & 29 & 142 & 23.4 \\
\hline Inceptisols & Nasik & 24.02 & 4.0 & 51.1 & 36.4 & 6.8 \\
\hline Alfisols & Bengaluru & 5.0 & 29.0 & 57.0 & 31.9 & 14.9 \\
\hline Aridisols & Gwalior & 28.5 & 2.4 & 50.2 & 112 & 27.5 \\
\hline
\end{tabular}


Table.3 Distribution of phosphorus fractions and its percent under different levels of phosphorus in vertisols

\begin{tabular}{|c|c|c|c|c|c|c|c|c|}
\hline \multirow{2}{*}{ Treatments } & \multicolumn{2}{|c|}{ Saloid-P } & \multicolumn{2}{c|}{ Al-P } & \multicolumn{2}{c|}{ Fe-P } & \multicolumn{2}{c|}{ Ca-P } \\
\cline { 2 - 9 } & Kg ha $^{-1}$ & \% & Kg ha $^{-1}$ & \% & Kg ha $^{-1}$ & \% & Kg ha $^{-1}$ & \% \\
\hline Control P & 9.0 & 4.7 & 12.0 & 6.3 & 29.0 & 15.1 & 142.0 & 73.9 \\
\hline $\mathbf{4 0 ~ K g ~ P ~}$ & 12.3 & 5.1 & 12.5 & 5.2 & 38.0 & 15.7 & 171.0 & 70.6 \\
\hline $\mathbf{8 0 ~ K g ~ P ~}$ & 15.2 & 5.2 & 13.4 & 4.6 & 53.0 & 18.0 & 196.0 & 66.6 \\
\hline $\mathbf{1 2 0}$ Kg P & 16.2 & 4.8 & 22.0 & 6.6 & 61.0 & 18.2 & 218.0 & 65.3 \\
\hline $\mathbf{1 6 0} \mathbf{~ K g ~ P ~}$ & 17.7 & 4.7 & 25.0 & 6.6 & 75.0 & 19.8 & 242.0 & 63.7 \\
\hline $\mathbf{2 0 0}$ Kg P & 18.3 & 4.3 & 32.0 & 7.6 & 88.0 & 20.9 & 263.0 & 62.4 \\
\hline $\mathbf{4 0 0} \mathbf{~ K g ~ P ~}$ & 20.0 & 3.1 & 38.0 & 5.9 & 112.0 & 17.5 & 432.0 & 67.4 \\
\hline Average & 15.5 & 4.6 & 22.1 & 6.1 & 65.1 & 17.9 & 237.7 & 67.1 \\
\hline
\end{tabular}

Table.4 Distribution of phosphorus fractions and its percent under different levels of phosphorus in inceptisols

\begin{tabular}{|c|c|c|c|c|c|c|c|c|}
\hline \multirow{2}{*}{ Treatments } & \multicolumn{2}{|c|}{ Saloid } & \multicolumn{2}{|c|}{ Al-P } & \multicolumn{2}{c|}{ Fe-P } & \multicolumn{2}{c|}{ Ca-P } \\
\cline { 2 - 10 } & Kg ha $^{-1}$ & \% & Kg ha $^{-1}$ & \% & Kg ha $^{-1}$ & \% & Kg ha $^{-1}$ & \% \\
\hline Control P & 24 & 12.5 & 4 & 2.1 & 69.7 & 26.9 & 51.5 & 36.4 \\
\hline $\mathbf{4 0 ~ K g ~ P ~}$ & 26 & 10.7 & 4.4 & 1.8 & 98 & 24.8 & 60 & 40.5 \\
\hline $\mathbf{8 0 ~ K g ~ P ~}$ & 34.4 & 11.7 & 6.6 & 2.2 & 119 & 23.5 & 69 & 40.5 \\
\hline $\mathbf{1 2 0} \mathbf{~ K g ~ P ~}$ & 38.6 & 11.5 & 7.3 & 2.2 & 148 & 22.4 & 75 & 44.2 \\
\hline $\mathbf{1 6 0} \mathbf{~ K g ~ P ~}$ & 42.8 & 11.3 & 12.9 & 3.4 & 177 & 20 & 76 & 46.6 \\
\hline $\mathbf{2 0 0} \mathbf{~ K g ~ P ~}$ & 45.5 & 10.8 & 14.5 & 3.4 & 200 & 21.1 & 89 & 47.5 \\
\hline $\mathbf{4 0 0} \mathbf{~ K g ~ P ~}$ & 74 & 11.5 & 17.8 & 2.8 & 338 & 18.6 & 119 & 52.7 \\
\hline Average & 40.8 & 11.4 & 9.6 & 2.6 & 164.2 & 22.5 & 77.1 & 44.05 \\
\hline
\end{tabular}

Table.5 Distribution of phosphorus fractions and its percent under different levels of phosphorus in Alfisols

\begin{tabular}{|c|c|c|c|c|c|c|c|c|}
\hline \multirow[t]{2}{*}{ Treatments } & \multicolumn{2}{|c|}{ Saloid-P } & \multicolumn{2}{|c|}{ Al-P } & \multicolumn{2}{|c|}{ Fe-P } & \multicolumn{2}{|c|}{ Ca-P } \\
\hline & $\mathrm{Kg} \mathrm{ha}^{-1}$ & $\%$ & $\mathrm{Kg} \mathrm{ha}^{-1}$ & $\%$ & $\mathrm{Kg} \mathrm{ha}^{-1}$ & $\%$ & $\mathrm{Kg} \mathrm{ha}^{-1}$ & $\%$ \\
\hline Control P & 5 & 4.1 & 29 & 23.6 & 57 & 46.4 & 31.9 & 25.9 \\
\hline $40 \mathrm{Kg} \mathrm{P}$ & 7.1 & 4.4 & 38 & 23.4 & 82 & 50.6 & 35 & 21.6 \\
\hline $80 \mathrm{Kg} \mathrm{P}$ & 11 & 5.5 & 48 & 23.9 & 100 & 49.8 & 42 & 20.9 \\
\hline $120 \mathrm{Kg} P$ & 12.3 & 5.1 & 61 & 25.2 & 120 & 49.5 & 49 & 20.2 \\
\hline $160 \mathrm{Kg} \mathrm{P}$ & 14 & 5 & 80 & 28.4 & 133 & 47.2 & 55 & 19.5 \\
\hline $200 \mathrm{Kg} \mathrm{P}$ & 21 & 6.5 & 98 & 30.4 & 141 & 43.8 & 62 & 19.3 \\
\hline $400 \mathrm{Kg} \mathrm{P}$ & 27 & 5.2 & 132 & 25.3 & 273.8 & 52.5 & 89 & 17.1 \\
\hline Average & 13.9 & 5.1 & 69.4 & 25.7 & 129.5 & 48.5 & 52 & 20.64 \\
\hline
\end{tabular}


Table.6 Distribution of phosphorus fractions and its percent under different levels of phosphorus in Aridisols

\begin{tabular}{|c|c|c|c|c|c|c|c|c|}
\hline \multirow{2}{*}{ Treatments } & \multicolumn{2}{|c|}{ Saloid-P } & \multicolumn{2}{|c|}{ Al-P } & \multicolumn{2}{|c|}{ Fe-P } & \multicolumn{2}{c|}{ Ca-P } \\
\cline { 2 - 10 } & Kg ha $^{-1}$ & $\%$ & Kg ha $^{-1}$ & $\%$ & Kg ha $^{-1}$ & $\%$ & Kg ha $^{-1}$ & $\%$ \\
\hline Control P & 25.8 & 13.5 & 2.4 & 1.3 & 50.2 & 26.2 & 112 & 58.4 \\
\hline $\mathbf{4 0 ~ K g ~ P ~}$ & 31.6 & 13 & 4 & 1.7 & 55 & 22.7 & 139 & 57.4 \\
\hline $\mathbf{8 0 ~ K g ~ P ~}$ & 33 & 11.2 & 5 & 1.7 & 62 & 21.1 & 170 & 57.9 \\
\hline $\mathbf{1 2 0}$ Kg P & 35 & 10.5 & 7 & 2.1 & 72 & 21.5 & 196 & 58.6 \\
\hline $\mathbf{1 6 0} \mathbf{~ K g ~ P}$ & 42 & 11.1 & 9.7 & 2.6 & 85 & 22.4 & 213 & 56.1 \\
\hline $\mathbf{2 0 0} \mathbf{~ K g ~ P}$ & 51 & 12.1 & 12.1 & 2.9 & 101 & 24 & 226.3 & 53.7 \\
\hline $\mathbf{4 0 0} \mathbf{~ K g ~ P}$ & 65 & 10.1 & 26 & 4.1 & 134 & 20.9 & 365 & 56.9 \\
\hline Average & 40.5 & 11.6 & 9.5 & 2.3 & 79.9 & 22.7 & 203 & 57 \\
\hline
\end{tabular}

Table.7 Correlation among the fractions of phosphorus by difference doses of Phosphorus applied in different soils

\begin{tabular}{|c|c|c|c|c|}
\hline Soil & Saloid & Al-P & Fe-P & Ca-P \\
\hline Vertisols & 0.87 & 0.95 & 0.97 & 0.99 \\
\hline Inceptisols & 0.99 & 0.94 & 0.99 & 0.94 \\
\hline Alfisols & 0.97 & 0.98 & 0.99 & 0.98 \\
\hline Aridisols & 0.98 & 0.99 & 0.98 & 0.997 \\
\hline
\end{tabular}

Fig.1 Saloid phosphorus fraction in different soils

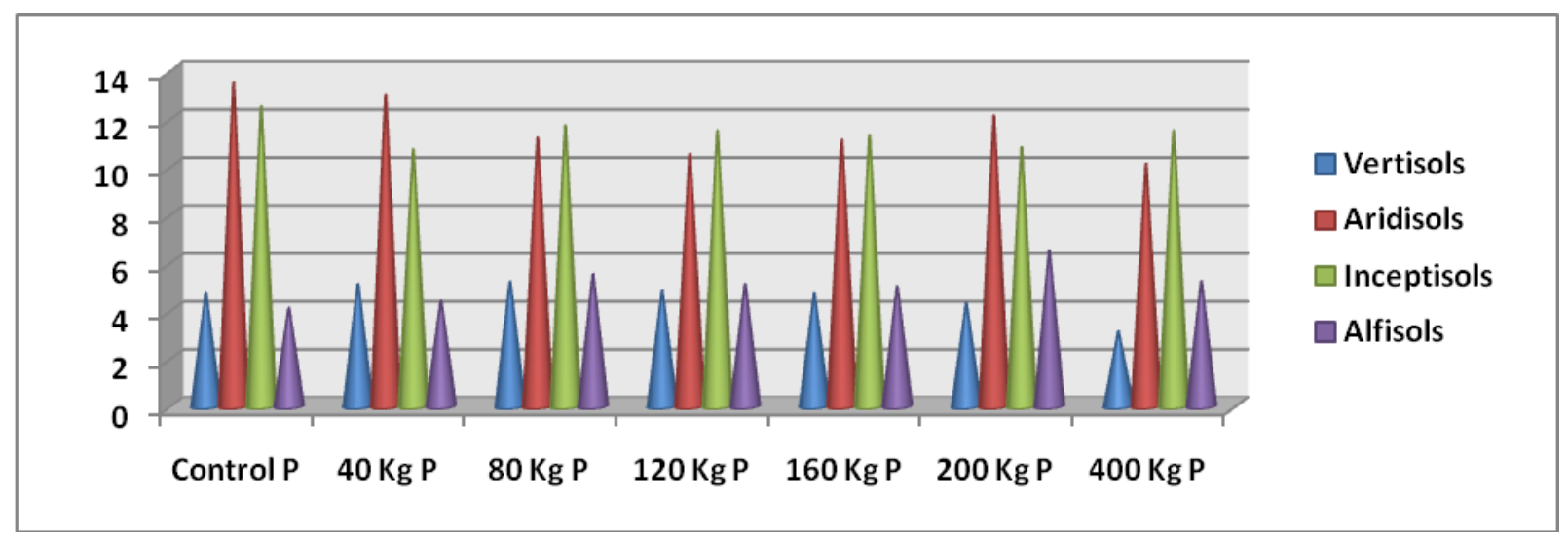


Fig.2 Aluminium bound phosphorus in different soils

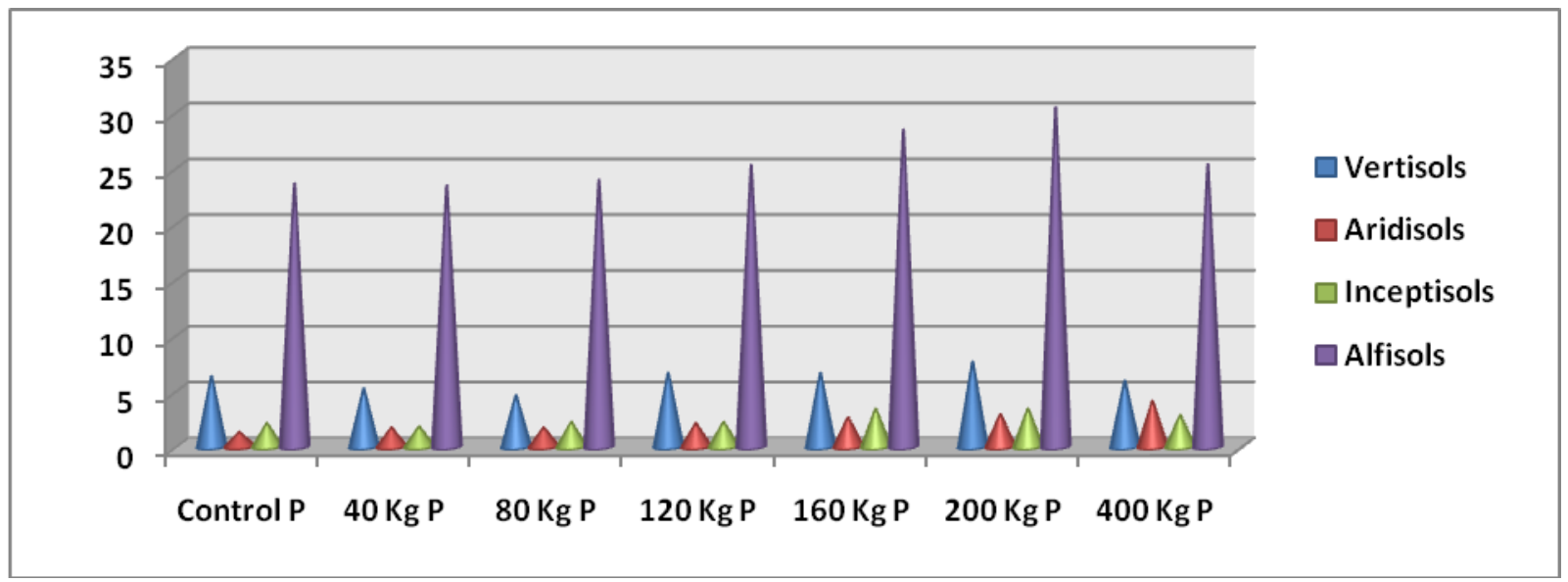

Fig.3 Iron bound phosphorus in different soils

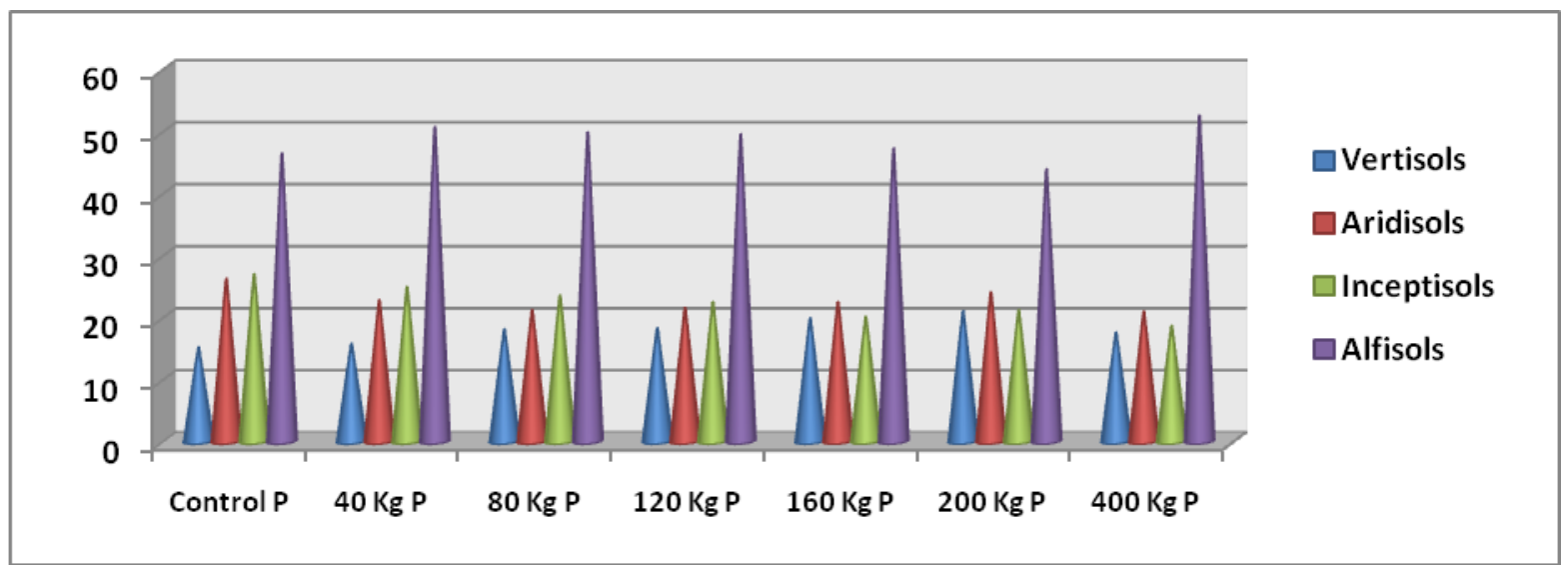

Fig.4 Calcium bound phosphorus in different soils

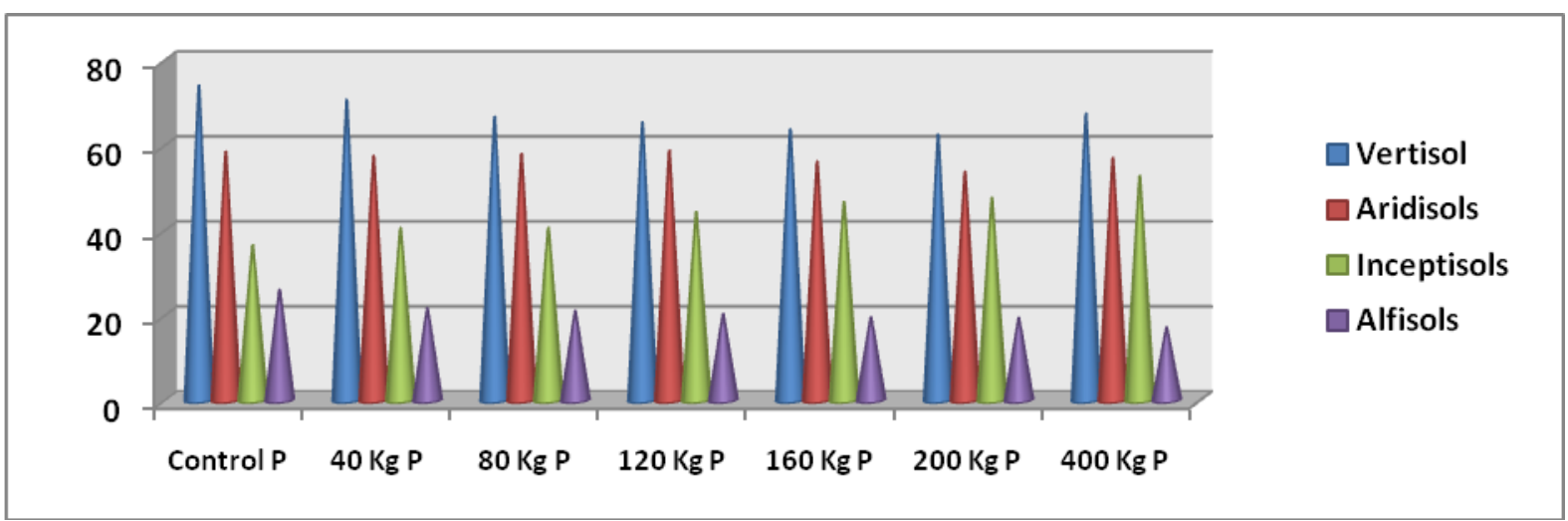

As regard to phosphorus fixation capacity of Vertisols, Alfisols, and Aridisols, the results are in conformity with the findings of
Motiramani et al., (1964), Gupta (1965),

Mustafa dulariraj (1968) and Maddanna Mallaiah (1971), Dou et al., (2009) Ghosal et 
al., (2011). The fixation increased with time up to $60^{\text {th }}$ days in Aridisols, as reported by David and Apte (1975). The fraction of phosphorus was significantly affected with time taken for incubation and soil type.

\section{Correlation among the fractions of phosphorus by difference doses of} Phosphorus applied in different soils

The data presented in Table 7 indicated that the correlation studies of different fractions of phosphorus under different rates of phosphorus application showed positive correlation with $\mathrm{Ca}-\mathrm{P}$ in Vertisols and Aridisols, while Fe - P, Al - P Showed highly significant correlation with Inceptisols and Alfisols, this can be infused that the applied phosphorus fixed as $\mathrm{Ca}-\mathrm{P}$ in Vertisols while in the case of Alfisols and Inceptisols, the applied phosphorus is fixed as $\mathrm{Al}-\mathrm{P}$ and $\mathrm{Fe}$ $\mathrm{P}$ and Saloid-P did not show much response to different fraction of phosphorus except in Vertisols. The results are in agreement with the findings of Fe-P was found higher in surface soil due to higher organic carbon content, higher amount of calcium carbonate was recorded at higher $\mathrm{pH}$ where iron activity was less to precipitate $\mathrm{P}$ into $\mathrm{Fe}$, Chandra Bhan and Harishankar (1973), Devra et al., (2014). The high organic carbon content increased the amount of Fe-P in studied area Al-P had significant positive correlation. Silt content showed significant and negative relationship with Fe-P. The Organic carbon had significance. Similar findings were also reported by Viswanath and Doddamani (1991) with Ca-P. Similar finding is reported by Lungamuana et al., (2012).

In conclusion, the order of different $\mathrm{P}$ fractions at the start of the present study was maintain the level of various $\mathrm{P}$ fractions resulted in buildup of Saloid and available $\mathrm{P}$ as well as other nutrients in soil. P Saloid bound $\mathrm{P}$ account for $92 \%$ variation in available $\mathrm{P}$, whereas high level of Saloid - P in such soil also maintained due to fixed forms of $\mathrm{Ca}-\mathrm{P}, \mathrm{Fe}-\mathrm{P}, \mathrm{Al}-\mathrm{P}$, Saloid - P. The increases in availability of $\mathrm{P}$ upon application of organics might be related partly to the decrease in $\mathrm{P}$ sorption due to competition between phosphate ions and organic molecules for $\mathrm{P}$ retention sites in the soil which can be available to growing crops further. The dominance of different inorganic $\mathrm{P}$ fractions in these soils followed the order Vertisol: Ca-P > Fe-P > Al-P > Saloid - P. followed by order Inceptisols: $\mathrm{Fe}-\mathrm{P}>\mathrm{Ca}-\mathrm{P}>$ Saloid-P > Al-P. Order Alfisols: Fe-P > Al-P $>\mathrm{Ca}-\mathrm{P}>$ Saloid-P. Followed by order Aridisols: Ca-P > Fe-P > Saloid-P > Al-P. It suggests that it is associated with $\mathrm{Ca}$ bound $\mathrm{P}$ and can be an important component of soil $\mathrm{P}$.

\section{References}

Bansal SK and Sekhon GS. 1994. Soil phosphorus in some Vertisols and crop response to phosphorus in these soils. Fertilizer News, 39:13-17.

Bray RH, and Kurtz LT. 1945. Determination of total, organic and available forms of phosphorus in soil. Soil Sci. 59: 39-45.

Chang SC and Jackson ML.1957. Fraction of soil phosphorus. Soil Sci. 84: 133-134.

Devra, P., S. R. Yadav and I. J. Gulati, 2014. Distribution of different phosphorus fractions and their relationship with soil properties in western plain of Rajasthan. Agropedology, 24(1): 20-28.

Dolui AK and Dasgupta M. 1998. Phosphate sorption- desorption characteristics of ferruginous soils (Alfisols) of eastern India. Agropedology, 8:76-83.

Dubliya J. 2011. Soil health assessment of dusty acre farm under JNKVV, Jabalpur, Madhya Pradesh. M.Sc. Thesis, JNKVV, Jabalpur (M.P.).

Garg AK and Milkha SA. 2010. Effect of long term fertilizer management and crop rotation on accumulation and 
downward movement of phosphorous in semi-arid subtropical irrigated soil. Communication in Soil Sci. and plant Ana. Vol. 41: 848-864.

Ghosal, Prabir; Chakraborty, Trishit; Banik, Pabitra. (Nov 2011). Phosphorus fixing capacity of the Oxic Rhodustalf-alfisol soil in the Chotanagpur plateau region of Eastern India. Agricultural Sciences., 24: 487-490.

Gupta, A.P. (1965). Studies on the distribution, fixation and availability of phosphate in soils of sugarcane growing tracts of Bihar and U.P. Agra Univ. J. Res. 14: 191-94.

Jackson ML. 1973. Soil Chemical Analysis. Prentice Hall of India, Private Limited New Delhi, 498p.

Kanwar, J. S. 1976. Soil fertility theory and practice (Indian Council of Agricultural Research, New Delhi).

Kaushal A.1995. Forms of phosphorus in typic Haplusterts and their availability to wheat under long term fertilizer application and intensive cropping. Ph.D. Thesis. JNKW. Jabalpur. Pp. 158160.

Lei, H., Zhu, C., Liu, X. 2004. Phosphorus adsorption desorption characteristics in acid soils under amendment. Acta Pedologica Sinica. 41, 636-640.

Lungmuana, S. K. Ghosh and P. K. Patra, 2012. Distribution of different forms of phosphorus in surface soil of rice Areas of red and latererite zone of West Bengal. J. Indian Soc. Soil Sci. vol 60(3): 204-207.

Matike DME, Ekosse GIE and Ngole VM. 2011. Physico-chemical properties of clayey soils used traditionally for cosmetics in Eastern Cape, South Africa. International Journal of the Physical Sciences 6(33): 7557-7566.

McBeath, T.M., Armstrong, R.D., Lombi, E., Mclaughlin, M.J. Holloway, R.E. 2005. Responsiveness of wheat (Triticum aestivum) to liquid and granular phosphorus fertilizers in southern Australian soils. Aust. J. Soil Res. 43, 203-212.

Muddanna, V. and Mallaiah, C. (1971). Studies on the fixation of phosphate by Hebbel tank soil. Mysore J.agric.Sci.5:1-6.

Muralidharudu Y, Sammi Reddy K, Mandal BN, Subba Rao A, Singh K and Sonekar S. 2011. GIS based soil fertility maps of different states of India. All India Coordinated Project on Soil Test Crop Response Correlation, Indian Institute of Soil Science, Bhopal pp: 1224.

Ojo AO, Adetunji MT and Okeleye KA. 2015. Soil fertility, phosphorus fractions, and maize yield as affected by poultry manure and single superphosphate. Int Scholarly Res Notices. Article ID 6162.

Olsen SR, Cole CV, Vatanabe FS and Dean LA. 1954. Estimation of available phosphorus in soil by extraction with sodium bicarbonate. Circular United States, Department of Agriculture 93(9): 1-19.

Patagundi MS, Channal HT and Satyanarayana T. 1996. Distribution pattern and availability of phosphorus in some Vertisols of Tungabhadra command, Karnataka. Karnataka J Agric. Sci. 9(1): 33-39.

Piper CS. 1950. Intel Science Publishers. Inc. New York. Richards LA. Diagnosis and improvement of saline and alkali soils. Soil and Plant Analysis USDA Agric. Handbook 60.

Ravikumar P and Somashekar RK. 2014. Spatial distribution of macronutrients in soils of Markandeya river basin, Belgaum, Karnataka, India. Proceedings of the International Academy of Ecology and Environmental Science 4(2): 81-94. 
Reddy D, Subba Rao A and Takkar PN. 1999. Effects of repeated manure and fertilizer phosphorus additions on soil phosphorus dynamics under soybean wheat rotation. Biology and Fertility of Soils 28:150-155.

Samadi A. 2006. Contribution of inorganic phosphorus fraction to plant nutrition in alkaline-calcareous soil. J. Agric. Sci. Techno. 8: 77-79.

Singh R, Puri G, Dilliwar P and Amule FC. 2014. Soil health assessment of Adhartal series under Jawaharlal Nehru Krishi Vishwa Vidyalaya. National conference on soil health: A key to unlock and sustain production potential September 3-4 2014 held at Department of Soil Science and Agricultural Chemistry, College of Agriculture, JNKVV, Jabalpur (M.P.).

Subbiah BV and Asija GL. 1956. A rapid procedure for the determination of available nitrogen in soils. Current Science 25(8): 259-260.
Turner BL, Richardson AE, Mullaney EJ 2007. Inositol phosphates in soil: amounts, forms and significance of the phosphorylated inositol stereoisomers. Inositol Phosphates; Linking Agriculture and the Environment. CABI, Wallingford, UK 186-206.

Walkley A and Black CA. 1934. An examination of Degt-Jreff method for determination soil organic matter and proposal for modification of the chromic acid titration method. Soil Science 37: 29-38.

Withers, P.J.A., Jarvie, H.P. 2008. Delivery and cycling of phosphorus in rivers, A review. Sci. Total Environ. 400, 379395.

Yang X and Post WM. 2011. Phosphorus transformations as a function of pedogenesis: A synthesis of soil phosphorus data using Hedley fractionation method. Biogeosciences 8(10): 2907-2916.

\section{How to cite this article:}

Tirunima Patle, V.K. Khaddar, Rishikesh Tiwari and Pavan Para. 2019. Phosphorus Fractions in Different Soil Orders in India and their Relationship with Soil Properties. Int.J.Curr.Microbiol.App.Sci. 8(05): 1609-1620. doi: https://doi.org/10.20546/ijcmas.2019.805.186 